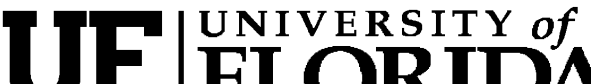 FLORIDA \\ IFAS Extension
}

\section{Strawberry Cultivar Evaluations in Florida: 2006-07 Season 1}

Bielinski M. Santos, Craig K. Chandler, Stephen M. Olson and Teresa W. Olczyk²

\section{Introduction}

Strawberry production represented approximately $\$ 240$ million in gross sales in Florida during the 2006-07 season (U.S. Department of Agriculture, 2007). Although the majority of the production areas are located in west central Florida, there is a considerable number of small farms in the northern and southern part of the peninsula. In all those locations, climatic conditions greatly change, especially in late fall and winter when most strawberries are planted in Florida. These environmental differences could translate into variations on cultivar performance.

Most of the strawberry cultivars planted in the U.S. and adopted worldwide come from breeding programs in California and Florida, which are the leading producing states in the country. Those cultivars have been bred to satisfy specific horticultural, flavor and marketing requirements in each state. For instance, most California cultivars tend to maximize yields under warm weather, which make these unsuitable for Florida conditions, where production occurs during winter. Varying requirements justify the existence of different breeding programs across the country. During the last two decades, several Florida-bred cultivars have been released and extensively planted, including 'Sweet Charlie', 'Earlibrite', 'Carmine', 'Strawberry Festival' and 'Winter Dawn'. One of the most important requirements for strawberry production is yield earliness, because it allows growers to have fruit when premium prices are available. Therefore, finding cultivars with high early yields is a desirable trait. The objective of this study was to compare cultivar performance in multiple locations throughout Florida.

\section{Statewide Cultivar Evaluations}

Three field studies were conducted simultaneously at Balm, Quincy and Homestead, Florida. In Balm, the trial was established at the Gulf Coast Research and Education Center of the University of Florida. The soil was Myakka deep sand with $1.5 \%$ organic matter and $\mathrm{pH} 7.3$. Planting beds were 32 inches wide at the base, 28 inches wide at the top, 8 inches high, and spaced $5 \mathrm{ft}$ apart on centers. Finished beds were fumigated with methyl bromide

1. This document is HS1120, one of a series of the Horticultural Sciences Department, Florida Cooperative Extension Service, Institute of Food and Agricultural Sciences, University of Florida. Original publication date October, 2007. Visit the EDIS Web Site at http://edis.ifas.ufl.edu.

2. Bielinski M. Santos and Craig K. Chandler, assistant professor and professor, respectively, Gulf Coast Research and Education Center; Stephen M. Olson, professor, North Florida Research and Education Center; Teresa W. Olczyk, extension agent, Miami-Dade County Extension Service, Cooperative Extension Service, IFAS, University of Florida, Gainesville, FL 32611

The Institute of Food and Agricultural Sciences (IFAS) is an Equal Opportunity Institution authorized to provide research, educational information and other services only to individuals and institutions that function with non-discrimination with respect to race, creed, color, religion, age, disability, sex, sexual orientation, marital status, national origin, political opinions or affiliations. U.S. Department of Agriculture, Cooperative Extension Service, University of Florida, IFAS, Florida A. \& M. University Cooperative Extension Program, and Boards of County Commissioners Cooperating. Larry Arrington, Dean 
plus chloropicrin $(67: 33 \mathrm{v} / \mathrm{v})$ at a rate of $350 \mathrm{lb} / \mathrm{acre}$ to eliminate soilborne diseases, nematodes and weeds in the soil. Simultaneously, beds were fertilized pre-transplant with $50 \mathrm{lb} /$ acre of a $15 \mathrm{~N}-0 \mathrm{P}-25 \mathrm{~K}$ granular formula, planting beds were covered with black, high-density polyethylene mulch, and drip irrigation tubing was buried 1 inch deep on the bed center. Plant nutrients were supplied to the crop through the drip lines following statewide recommendations (Peres et al., 2006). In this experimental site, plots were established under 12-ft-high passively ventilated tunnels. Planting dates were September 27 for 'Camarosa'; October 4 for 'Albion', 'Treasure', and 'Winter Dawn'; 10 October for '00-51', and 22 October for 'Carmine', 'Camino Real', and 'Strawberry Festival'.

In Quincy, the soil at the North Florida Research and Education Center of the University of Florida was a fine-loamy soil with $\mathrm{pH} 6.4$ and $<1 \%$ organic matter content. Planting beds were 34 inches wide on base and 8 inches tall. 'Albion', 'Treasure', and 'Winter Dawn' were planted on 16 October; 'Carmine' and 'Strawberry Festival' were established on 18 October; and 'Camarosa' and 'Camino Real' were planted on 26 October. The Homestead trial was established in a grower's field and the soil was classified as a very gravelly loam soil with $\mathrm{pH} 6.5$ and $<2 \%$ organic matter content. Planting beds were 36 inches wide on base and 6 inches tall. Two drip irrigation lines separated 14 inches from each other were placed on each bed. Planting dates were 13 October for 'Albion', 'Carmine', 'Strawberry Festival', 'Treasure', and 'Winter Dawn'; and 26 October for 'Camarosa' and 'Camino Real'. In Quincy and Homestead, mulching, soil fumigation, drip irrigation and fertilization were similar to those procedures previously described. Bare-root transplants from nurseries in Canada were established 15 inches apart in double rows in Balm and Quincy, and in triple rows in Homestead. The tested cultivars were 'Albion', 'Camino Real', 'Camarosa', 'Carmine', 'Strawberry Festival', 'Treasure', 'Winter Dawn', and the advanced line '00-51' from the University of Florida strawberry breeding program. The latter was only established in Balm. The crop was harvested 22, 27 and 16 times in Balm, Homestead, and Quincy, respectively. Early yield was defined as the total marketable fruit of the first eight harvests.

There were significant differences on early and total strawberry yield among cultivars at all three locations. At Balm, the highest early yield was obtained with '00-51' (8.4 ton/acre), followed by 'Winter Dawn', 'Carmine', 'Albion', and 'Strawberry Festival', which ranged between 5.4 and 6.4 ton/acre (Table 1). 'Winter Dawn' had the best performance over the duration of the whole season, producing more than 34 ton/acre. There were no differences in the total yields of 'Carmine', 'Albion', 'Strawberry Festival', 'Camarosa', '00-51', which ranged between 20.7 and 24.8 ton/acre.

At the Homestead location, 'Strawberry Festival', 'Carmine', and 'Camino Real' had the highest early yields, ranging between 2.2 and 1.8 ton/acre (Table 1). 'Winter Dawn' and 'Camarosa' had the same early production as 'Camino Real' and 'Carmine'. The total yield of 'Winter Dawn', 'Strawberry Festival' and 'Camarosa' were not significantly different. In Quincy, 'Strawberry Festival' and 'Winter Dawn' had the highest early yield (3.9 ton/acre) among all cultivars, whereas 'Camarosa' and 'Strawberry Festival' had the highest season-long production, ranging between 9.7 and 11.6 ton/acre.

These results indicated that the Florida cultivars 'Winter Dawn' and 'Strawberry Festival' consistently were among the ones with the highest early and total marketable yield at all three experimental sites. The total yields of the California cultivar 'Camarosa' were comparable to those of 'Strawberry Festival' in all three locations. The advanced line '00-51' seems to be a promising strawberry germplasm due to its earliness and total yields, but further evaluations are needed.

\section{Literature Cited}

Peres, N.A., J.F. Price, W.M. Stall, C.K. Chandler, S.M. Olson, T.G. Taylor, S.A. Smith, and E.H. Simonne. 2006. Strawberry production in Florida, p. 375-382. In: S.O. Olson and E.H. Simonne (eds.). Vegetable production handbook for Florida, 2006-2007. Inst. Food Agr. Sci. Publ., Univ. of Florida, Gainesville. 
SAS Institute. 2000. SAS user's guide. Version 8.1. SAS Inst., Cary, NC.

U.S. Department of Agriculture. 2007.

Vegetables: 2006 Summary. 6 Mar. 2007.

<http://www.nass.usda.gov>. 
Table 1. Comparison of early and total marketable yield of strawberry cultivars in three locations in Florida, 2006-07.

\begin{tabular}{|c|c|c|c|c|c|c|}
\hline \multirow[t]{3}{*}{ Cultivars } & \multicolumn{2}{|l|}{ Balm } & \multicolumn{2}{|l|}{ Homestead } & \multicolumn{2}{|l|}{ Quincy } \\
\hline & Early yield $^{2}$ & Total yield & Early yield & Total yield & Early yield & Total yield \\
\hline & \multicolumn{6}{|c|}{ - } \\
\hline Winter Dawn & $6.4 \mathrm{~b}$ & $34.4 \mathrm{a}$ & $1.5 \mathrm{bc}$ & $7.4 \mathrm{a}$ & $3.9 \mathrm{a}$ & $8.0 \mathrm{bc}$ \\
\hline Carmine & $6.2 \mathrm{~b}$ & $24.8 \mathrm{~b}$ & $1.8 \mathrm{ab}$ & $5.8 \mathrm{~b}$ & $2.0 \mathrm{bc}$ & $5.6 \mathrm{de}$ \\
\hline Albion & $5.2 \mathrm{~b}$ & $22.9 \mathrm{bc}$ & $1.0 \mathrm{~d}$ & $3.6 \mathrm{c}$ & $1.1 \mathrm{~d}$ & $4.4 \mathrm{e}$ \\
\hline Strawberry Festival & $5.4 \mathrm{~b}$ & $21.6 \mathrm{bc}$ & $2.2 \mathrm{a}$ & $7.4 \mathrm{a}$ & $3.9 \mathrm{a}$ & $9.7 \mathrm{ab}$ \\
\hline Camarosa & $2.2 \mathrm{c}$ & $20.7 \mathrm{bcd}$ & $1.6 \mathrm{bc}$ & $6.2 \mathrm{ab}$ & $2.6 \mathrm{~b}$ & $11.6 \mathrm{a}$ \\
\hline Treasure & $2.9 \mathrm{c}$ & $18.2 \mathrm{~cd}$ & $1.2 \mathrm{~cd}$ & $4.5 \mathrm{c}$ & $1.2 \mathrm{~cd}$ & $5.3 \mathrm{e}$ \\
\hline Camino Real & $0.9 \mathrm{~d}$ & $15.9 \mathrm{~d}$ & $1.9 \mathrm{ab}$ & $6.0 \mathrm{~b}$ & $2.3 \mathrm{~b}$ & $7.4 \mathrm{~cd}$ \\
\hline $00-51$ & $8.4 \mathrm{a}$ & $21.0 \mathrm{bc}$ & --- & --- & $-\ldots$ & ---- \\
\hline
\end{tabular}

\footnotetext{
${ }^{z}$ Values followed by the same letter within each fruit category do not differ at the $5 \%$ significance level.
} 